\title{
Hepatopancreatic parvo-like virus (HPV) of Penaeus japonicus cultured in Australia
}

\author{
K. M. Spann ${ }^{1, *}$, R. D. Adlard ${ }^{2}$, D. A. Hudson ${ }^{2}$, S. B. Pyecroft ${ }^{2}$, T. C. Jones ${ }^{2}$, M. O. C. Voigt ${ }^{2}$ \\ ${ }^{1}$ Department of Parasitology, The University of Queensland, Brisbane, 4072, Australia \\ ${ }^{2}$ Aquatic Diagnostic Services International, Pty, Ltd, PO Box 132, Toowong, Brisbane, 4066, Australia
}

\begin{abstract}
A hepatopancreatic parvo-like virus (HPV) infection was identified in the hepatopancreata of moribund Penaeus japonicus postlarvae from a hatchery in Queensland. The virus formed basophilic, fine granular intranuclear inclusion bodies within the hepatopancreocytes. These caused nuclear hypertrophy and displacement of the nucleolus. Subspherical viral particles, $17-20 \mathrm{~nm}$ in diameter, were observed embedded within the inclusions. We will refer to this virus as HPV to avoid confusion within the literature. However, molecular data is required to definitively identify this virus as $\mathrm{HPV}$
\end{abstract}

KEY WORDS: HPV - Penaeus japonicus

Of the 13 virus types which have been described from penaeid shrimp worldwide, 3 of these are parvo, or parvo-like viruses (Lightner 1996). Hepatopancreatic parvo-like virus (HPV; Lightner \& Redman 1985) has been documented from 7 penaeid species, including Penaeus esculentus (Paynter et al. 1985) and $P$. merguiensis (Roubal et al. 1989) from Australia. HPV infections have been linked to disease. However, they are often accompanied by other hepatopancreatic pathogens. Infectious hypodermal and hematopoietic necrosis virus (IHHNV; Lightner et al. 1983) can infect 10 penaeid species in Asia and the Americas (Brock \& Lightner 1990, Lightner 1996). An IHHNV-like virus has been reported from a hybrid penaeid shrimp bred in Australia (Owens et al. 1992). IHHNV infects cells of ectodermal and mesodermal origin (Lightner et al. 1983) and causes disease and mortality in juveniles. Lymphoidal parvo-like virus (LPV; Owens et al. 1991) has only been observed in cultured $P$. monodon, $P$. merguiensis and $P$. esculentus from Australia and is not associated with disease.

- Present address: CSIRO, Tropical Agriculture, PB3, Indooroopilly 4068, Australia. E-mail: kirsten.spann@tag.csiro.au
Materials and methods. Forty moribund Penaeus japonicus postlarvae (PL1) were collected from a hatchery in Queensland, Australia, and processed for light and transmission electron microscopy (TEM). Some postlarvae were fixed whole in Davidson's fixative $120 \%$ formaldehyde, $30 \%$ ethanol, $10 \%$ glacial acetic acid, $40 \%$ tap water) overnight, then transferred to $70 \%$ ethanol and passed through a dehydrating series of ethanol concentrations. Tissues were cleared in methyl salicylate, wax embedded and sectioned at $5 \mu \mathrm{m}$. Sections were stained with haematoxylin and eosin (H\&E).

The gnathothoraces (cephalothoraces minus the carapace, walking legs and mouthparts) of 10 postlarvae were fixed in $2.5 \%$ gluteraldehyde $2 \%$ paraformaldehyde in cacodylate buffer. Tissues were post-fixed in $1 \%$ osmium tetroxide, dehydrated through a graded series of ethanol and mounted in Spurr's resin (Spurr 1969). Semi-thin sections were cut at $0.9 \mu \mathrm{m}$, stained with $0.5 \%$ Toluidine blue in Borax and the area of interest identified using a compound microscope. Ultrathin sections were then cut at $50 \mathrm{~nm}$, mounted on $\mathrm{Cu}-200$ copper grids, stained with uranyl acetate $/ 70 \%$ methanol and Reynold's lead citrate and viewed at $80 \mathrm{kV}$ under a Jeol 1010 TEM.

Results. Infected postlarvae had atrophied hepatopancreata and the abdominal musculature was opaque. Histologically, singular, prominent, basophilic inclusion bodies (IBs) were observed in the nuclei of 2 to $10 \%$ of hepatopancreatic epithelial cells for all 30 postlarvae sampled (Fig. 1). Gills, heart, midgut and muscle appeared normal. By TEM the intranuclear IBs appeared ovoid to spherical, varied in diameter from 5 to $12 \mu \mathrm{m}$ and were composed of fine granular material (Fig. 2). They caused hypertrophy of infected nuclei and lateral displacement and compression of the host cell nucleolus (Fig. 2). Margination of host chromatin 


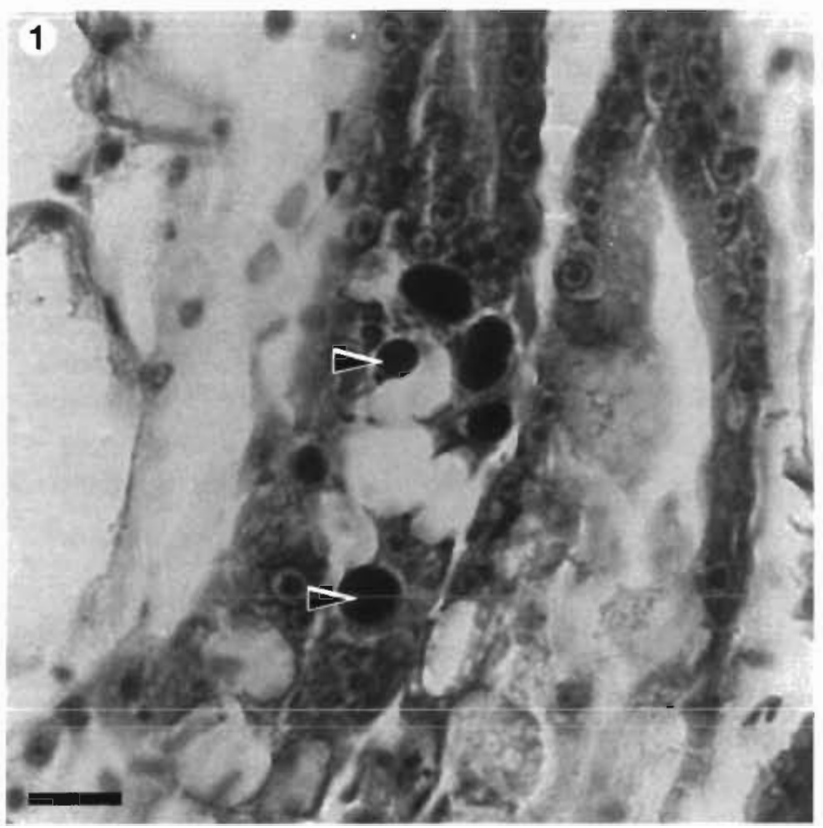

Fig. 1. Penaeus japonicus. Basophilic inclusion bodies (arrows) formed by HPV within the hepatopancreocytes of a diseased PL1 postlarvae. H\&E stain. Scale bar $=5 \mu \mathrm{m}$

was common. Viral particles, 17 to $20 \mathrm{~nm}$, were embedded in the IB and appeared to be unenveloped and roughly spherical (Fig. 3).

Discussion. The presence of roughly spherical viral particles within the nucleus of the host cells is indica-

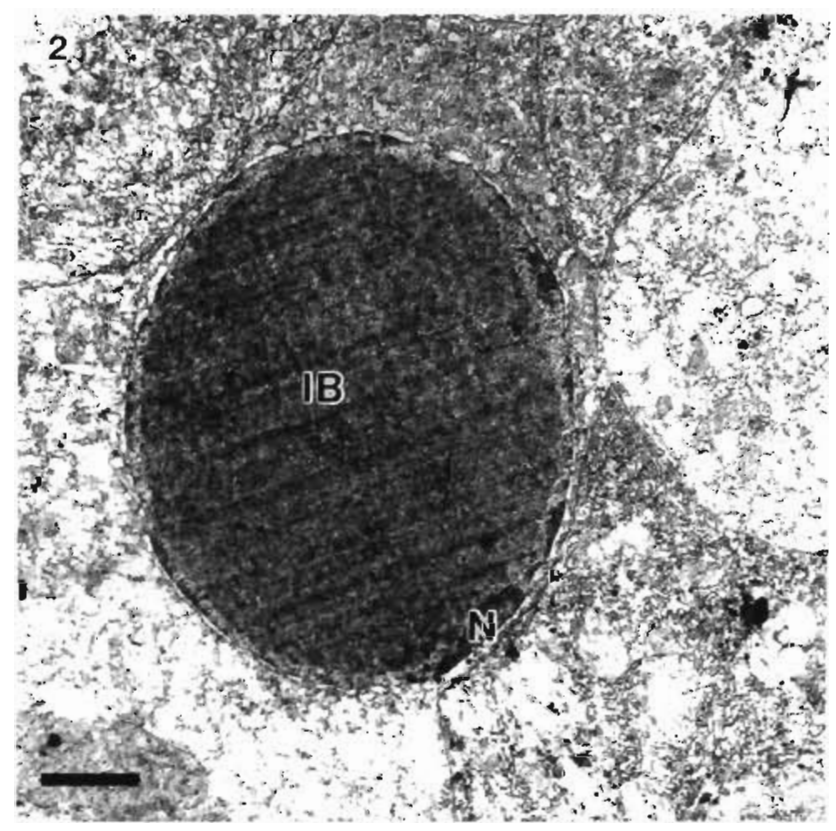

Fig. 2. Penaeus japonicus. An intranuclear HPV inclusion body (IB) causing hypertrophy of the nucleus and lateral displacement and compression of the nucleolus $(N)$ within a hepatopancreatic cell of $P$. japonicus postlarvae. Scale bar $=1 \mu \mathrm{m}$

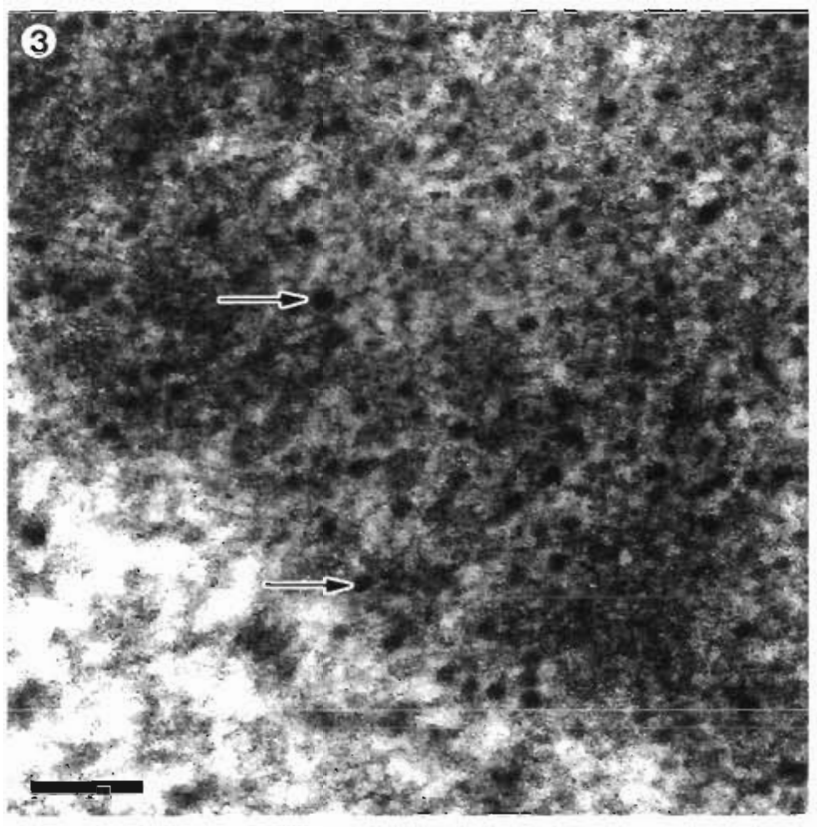

Fig. 3. Penaeus japonicus. HPV within the nucleus of a hepatopancreocyte. Unenveloped, roughly spherical P-PJ virus particles (arrows), 17 to $20 \mathrm{~nm}$ in diameter, embedded in an inclusion body which is composed of fine granular material. Scale bar $=100 \mathrm{~nm}$

tive of the family Parvoviridae. The morphology of the virus particles observed in the moribund Penaeus japonicus postlarvae closely resembles that of other parvoviruses and they overlap the size range for viruses within this family, which is 18 to $26 \mathrm{~nm}$ (Berns et al. 1995). The virus described here is most similar to the Densovirinae subfamily whose members infect invertebrates (Berns et al. 1995).

The virus observed in the moribund postlarvae is closely related to HPV as they are identical in morphology and cytopathology. Natural infections of HPV have been reported from many species worldwide including Penaeus japonicus (Lightner 1996). Signs of HPV such as an atrophied hepatopancreas and opaque abdominal muscles (Lightner \& Redman 1985), were observed for the diseased $P$. japonicus investigated here. HPV and HPV-like viruses infect the epithelial cells of the hepatopancreas and form distinct, singular, basophilic IBs, composed of electrondense, finely granular material (Lightner \& Redman 1985, Paynter et al. 1985, Roubal et al. 1989). HPV IBs, when fully formed, cause nuclear hypertrophy and compression and displacement of the host cell nucleolus. The virus particles described here are smaller than those of HPV from P. merguiensis (21 to $22 \mathrm{~nm}$; Roubal et al. 1989) and other species (22 to $24 \mathrm{~nm}$; Lightner 1988). However, this may be due to differences in treatment of the tissues. 
HPV has been linked to disease and mortality in juvenile prawns, but is seldom observed alone in epizootics with high mortality rates. This differs from the strain of HPV described here, which did not appear to be associated with other pathogens and is a serious pathogen of postlarvae. Lightner et al. (1993) have suggested that HPV may be a serious primary pathogen of younger life stages and that past difficulties in diagnosis may have caused it to be overlooked.

IHHNV has been documented from Penaeus japonicus and the viral particles reported here are similar in size (Brock \& Lightner 1990). However, IHHNV replication occurs in the cytoplasm, not the nucleus and it rarely infects the hepatopancreas (Lightner et al. 1983). LPV is an intranuclear virus and particles are the same size as those reported here (Owens et al. 1991). However, LPV does not infect the hepatopancreas and has not been recorded from $P$. japonicus.

The virus reported here may be regarded as HPV. However, molecular data is required to determine the appropriate taxonomic classification of the virus.

Acknowledgements. This research was funded by the Aquaculture CRC Ltd, with support from the hatchery under investigation and Aquatic Diagnostic Services International Pty, Ltd.

\section{LITERATURE CITED}

Berns KI, Bergoin $M$, Bloom M, Lederman M, Muzyczka $N$, Siegl G, Tal J, Tattersall P (1995) Parvoviridae ln: Murphy FA, Fauquet CM, Bishop DHL, Ghabrial SA, Jarvis AW,

Editorial responsibility: Timothy Flegel,

Bangkok, Thailand
Martelli GP, Mayo MA, Summers MD (eds) Virus taxonomy, Sixth Report of the International Committee on Taxonomy of Viruses. Springer-Verlag, Vienna, p 160-178

Brock JA, Lightner DV (1990) Diseases of Crustacea. In: Kinne $O$ (ed) Diseases of marine animals, Vol 3. Biologische Anstalt Helgoland, Hamburg, p 245-424

Lightner DV (1988) Diseases of cultured penaeid shrimp and prawns. In: Sindermann CJ, Lightner DV (eds) Disease diagnosis and control in North American marine aquaculture, 2nd edn. Elsevier, New York, p 8-127

Lightner DV (ed) (1996) A handbook of shrimp pathology and diagnostic procedures for disease of cultured penaeid shrimp. World Aquaculture Society, Baton Rouge

Lightner DV, Redman RM (1985) A parvo-like virus disease of penaeid shrimp. J Invertebr Pathol 45:47-53

Lightner DV, Redman RM, Bell TA (1983) Infectious hypodermal and hematopoietic necrosis, a newly recognized virus disease in penaeid shrimp. J Invertebr Pathol 42:62-70

Lightner DV, Redman RM, Moore DW, Park MA (1993) Development and application of a simple and rapid diagnostic method to studies on hepatopancreatic parvovirus of penaeid shrimp. Aquaculture 116:15-23

Owens L, Anderson IG, Kenway M, Trott L, Benzie JAH (1992) Infectious hypodermal and hematopoietic necrosis virus (IHHNV) in a hybrid penaeid prawn from tropical Australia. Dis Aquat Org 14:219-228

Owens L, De Beer S, Smith J (1991) Lymphoidal parvoviruslike particles in Australian penaeid prawns. Dis Aquat Org 11:129-134

Paynter JL, Lightner DV, Lester RJG (1985) Prawn virus from juvenile Penaeus esculentus. In: Rothlisberg PC, Hill BJ, Staples DJ (eds) Second Australian National Prawn Seminar. NPS2, Cleveland, p 61-64

Roubal FR, Paynter JL, Lester RJG (1989) Electron microscopic observation of hepatopancreatic parvo-like virus (HPV) in the penaeid prawn, Penaeus merguiensis de Man from Australia. J Fish Dis 12:199-201

Spurr AR (1969) A low viscocity epoxy resin embedding medium for electron microscopy. J Ultrastr Res 26:31-43

Subnitted: February 13, 1997; Accepted: October 14, 1997

Proofs received from author(s): December 24, 1997 